\title{
Speleothem evidence for temporal-spatial variation in the East Asian Summer Monsoon since the Medieval Warm Period
}

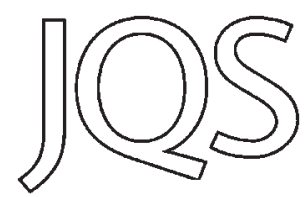

\author{
PETER C. CHU, ${ }^{1}$ HONG-CHUN LI, ${ }^{2,3 *}$ CHENWU FAN ${ }^{1}$ and YONG-HENG $\mathrm{CHEN}^{3}$ \\ ${ }^{1}$ Department of Oceanography, Naval Postgraduate School, Monterey, California, USA \\ ${ }^{2}$ Department of Geosciences, National Taiwan University, Taipei, Taiwan, ROC \\ ${ }^{3}$ School of Environmental Science and Engineering, Guangzhou University, Guangzhou, China \\ Received 31 August 2011; Revised 18 March 2012; Accepted 26 July 2012
}

\begin{abstract}
Published annual-to-decadal-resolution stalagmite $\delta^{18} \mathrm{O}$ records since AD 900 from six caves (Dongge, Furong, Heshang, Buddha, Shihua and Wanxiang) in China were analyzed to detect temporal and spatial variability of the East Asian Summer Monsoon strength, which strongly affects wet/dry conditions in eastern China. The empirical mode decomposition method was used to obtain trends of the six cave records. After the base trend was determined, $\delta^{18} \mathrm{O}$ anomalies of each record were computed by subtracting the base trend. Mean $\delta^{18} \mathrm{O}$ anomaly values of the detrended time series for each cave record were calculated for four periods: (i) Medieval Warm Period (MWP; AD 900 1250): (ii) Little Ice Age phase 1 (LIA-1; AD 1250-1550); (iii) Little Ice Age phase 2 (LIA-2; AD 1550-1850); and (iv) modern period (MD; AD 1850-2000). From these anomalies, the temporal and spatial variability of wet/dry conditions has been identified. Positive values of the mean $\delta^{18} \mathrm{O}$ anomalies indicating drier conditions appeared in the lower Yangtze River Drainage Area and Southeast Coast Area during MD-1, LIA-1 and MWP, whereas negative values existed in north, south and Yangtze areas of eastern China during LIA-2. The results agree with the dryness/wetness index reconstructed by Chinese historic records in general. These results illustrate that wet and dry conditions in different regions of eastern China could be opposite under monsoon influence, so that no single speleothem $\delta{ }^{18} \mathrm{O}$ record could represent the monsoonal climate in this vast region. Climatic patterns in the monsoonal region can be either a combination of warm/wet and cold/dry or a combination of cold/wet and warm/dry on annual-tocentennial scales. A 128-year periodic cycle exists in all six cave records, whereas 64-year (possibly a harmonic of 128-year periodicity) and 42-year periodicities appear in Shihua, Heshang and Dongge records. These cycles may reflect the influence of solar activity on the East Asian Summer Monsoon. Copyright (C) 2012 John Wiley \& Sons, Ltd.
\end{abstract}

KEYWORDS: $\quad$ speleothem $\delta^{18} \mathrm{O}$ records; East Asian Summer Monsoon; empirical mode decomposition method; Medieval Warm Period; Little Ice Age.

\section{Introduction}

The East Asian Monsoon (EAM) is the annual wind direction change caused by a pressure gradient due to the thermal contrast between ocean and land surfaces. These pressure gradients draw moist air masses landward during the summer monsoon, supplying much precipitation to eastern China. During the winter, flow patterns are reversed, and cool, dry air dominates over eastern China. Long-term fluctuations in East Asian Summer Monsoon (EASM) intensity are linked to glacial/ interglacial cycles (change of ice volume) and orbital forcing. Precisely dated speleothem records have provided a history of EASM with lighter $\delta^{18} \mathrm{O}$ denoting stronger EASM with heavier precipitation (Hu et al., 2008; Ku and Li, 1998; Li et al., 1998a, 2011; Paulsen et al., 2003; Wan et al., 2011a; Wang et al., 2001; Yuan et al., 2004). On the basis of extremely sparse spatial coverage of proxy data such as lacustrine, marine sediments and speleothem sequences, it is known that the EAM system was stronger (weaker) in boreal winters but weaker (stronger) in boreal summers during glacial (interglacial) periods (e.g. Ding et al., 1995; Wang et al., 2008, 2010). For example, using 5-year-resolution absolute-dated speleothem $\delta{ }^{18} \mathrm{O}$ data at one location (Dongge Cave) in southern China, Wang et al. (2005) found pronounced changes in EASM intensity for the past 9000 years, which broadly follows the summer insolation, and is also punctuated by eight weak monsoon events lasting around one to five centuries. Up until now, almost all the studies on speleothem evidence for the EASM change are concentrated on the temporal variation.

*Correspondence: H.-C. Li, Department of Geosciences, as above. E-mail: hcli1960@ntu.edu.tw
Zhang et al. (2008) used $\delta^{18} \mathrm{O}$ in stalagmite WX42B from Wanxiang Cave located in Gansu Province of China as a proxy for EASM strength and interpreted the effect of changes in EASM strength on the rise and fall of Chinese dynasties. However, monsoonal rainfall in eastern China under the influence of the EAM is characterized by large variability in space and time (Ding and Ren, 2008; Guo et al., 2003; Shi et al., 1996). The influence of temporal change of EASM strength has spatial variation (Zhang et al., 2010, and references therein). Figure 1 shows the correlations of June-August rainfall patterns with summer monsoon strength based on the data of 160 meteorological stations in China (Guo et al., 2003). Summer monsoon indices (SMI) were reconstructed using sea-level pressure difference $(\leq-5 \mathrm{hPa})$ between land $\left(110^{\circ} \mathrm{E}\right)$ and sea $\left(160^{\circ} \mathrm{E}\right)$ over latitudes of $10-50^{\circ} \mathrm{N}$ in June-August. The influence is expressed by rainfall during the 10-year period (1988-1997) of weakest EASM minus rainfall at the same station during the 10-year period (1955-1964) of strongest EASM. It is seen that weaker EASM gave rise to less rainfall in northern China, but more rainfall in the middle-lower reaches of the Yangtze River and in southern coastal areas. Using dryness/wetness index (DWI) reconstructed from historic records, Zhang et al. (2010) also obtained spatial variations of the monsoonal rain in four different regions. Therefore, modern meteorological observations and historic records tell us that a strong summer monsoon can cause wet conditions in a region but dry conditions in another region in eastern China. No single speleothem $\delta^{18} \mathrm{O}$ record can represent the variation in monsoonal precipitation of the whole of eastern China.

Recent debates about the physical meaning of speleothem $\delta^{18} \mathrm{O}$ record in the paleoclimate community have focused on how speleothem $\delta^{18} \mathrm{O}$ reflects summer monsoon intensity and 


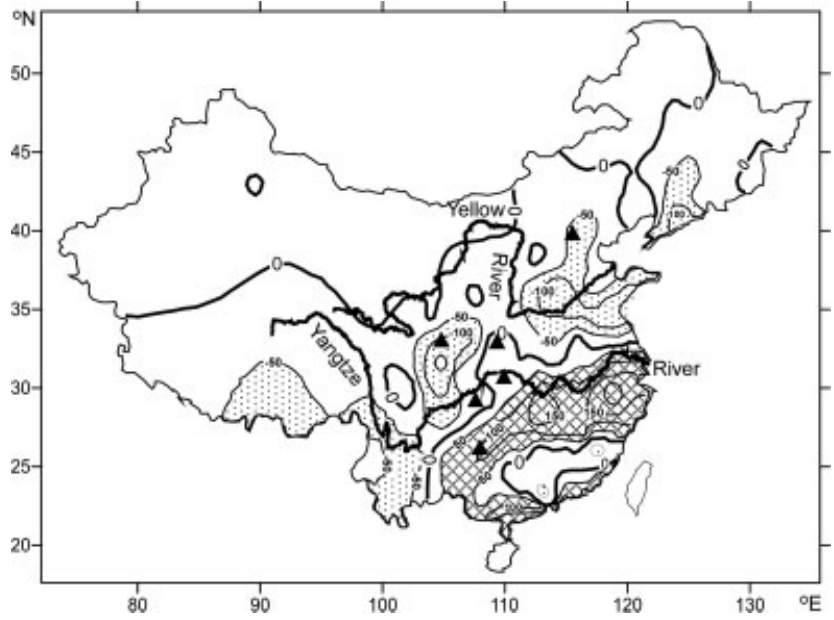

Figure 1. Influence of EASM on summer rainfall in China during AD 1951-2000 (modified from Guo et al., 2003). The influence is expressed by rainfall during the 10-year period (1988-1997) of weakest EASM minus rainfall at the same station during the 10-year period (1955-1964) of strongest EASM. The thick contours with number 0 indicate no difference. The thin contour lines with numbers show rainfall differences $(\mathrm{mm})$. Crossed areas give positive values and dotted areas negative values. Triangles denote locations of the six caves discussed in the paper.

rainfall. As changes in temperature, rainfall, upper stream rainout effect, moisture source pathway and $\delta^{18} \mathrm{O}$ of moisture source all can affect speleothem $\delta^{18} \mathrm{O}$ record (Wan et al., 2011a, 2011b, and references therein), a different frequency of speleothem $\delta^{18} \mathrm{O}$ record may have different main forcing factors. For instance, a low frequency $\left(>10^{3}\right.$ years $)$ of speleothem $\delta^{18} \mathrm{O}$ record variation may reflect regional or global forcing such as changes in global ice volume, solar insolation and/or ocean circulation, whereas high-frequency variations in the speleothem $\delta^{18} \mathrm{O}$ record may reflect local rainfall changes. Thus finding an appropriate analytical method for understanding the different frequency bands, anomaly after detrending and cyclicity of a speleothem $\delta^{18} \mathrm{O}$ record will help us to explain the physical meaning of the speleothem $\delta^{18} \mathrm{O}$ record in general.

To what extent do the Chinese speleothem $\delta^{18} \mathrm{O}$ records provide climatic condition in terms of precipitation? How does one extract the variation of monsoonal rainfall from a speleothem $\delta^{18} \mathrm{O}$ ? Is there any evident spatial variability of EASM in short duration since the late Holocene represented by Chinese speleothem records? To answer these questions, highresolution $\delta{ }^{18} \mathrm{O}$ data (yearly) since AD 900 constructed from speleothems at six caves (Dongge, Furong, Heshang, Buddha, Shihua and Wanxiang) in eastern China are used to identify the spatial inhomogeneity of EASM fluctuation. In this study, we will use empirical mode decomposition (EMD) (Huang et al., 1998) to detect the trends of the six high-resolution $\delta^{18} \mathrm{O}$ records. The anomalies of the $\delta^{18} \mathrm{O}$ time series (relative to the trends) are determined at each cave and the dipole pattern is obtained after calculating the mean anomalies at four climate periods: Medieval Warm Period (MWP), Little Ice Age phase 1 (LIA-1), Little Ice Age phase 2 (LIA-2) and modern period (MD). We then carry out spectral analysis on the anomalous $\delta^{18} \mathrm{O}$ records to detect any cycles and discuss their significance. Since the six records have good chronology control and the age uncertainties of the records are much smaller than the study durations, the age problem is not an issue here. In order to evaluate our results, the DWIs reconstructed from historic documents in eastern China have been analyzed. Our study initiates a new approach to using high-resolution paleoclimatic records for understanding the mechanisms and forcing factors of monsoonal climate changes.

\section{Speleothem $\delta^{18} \mathrm{O}$ records and DWI}

Calcite cave deposits can effectively record climatic variability occurring at different timescales over the Late Pleistocene (BarMatthews et al., 2003; Fairchild et al., 2006; McDermott, 2004). They are among the most widely distributed in continental environments, and are amenable to precise dating by lamination counting and uranium series $\left({ }^{230} \mathrm{Th} /{ }^{234} \mathrm{U}\right.$ and ${ }^{210} \mathrm{~Pb}$ ) dating (Baskaran and Iliffe, 1993; Edwards et al., 1986/ 87; Richards and Dorale, 2003; Ludwig et al., 1992; Shen et al., 2002; Shopov et al., 1994; Tan et al., 2002). The $\delta^{18} \mathrm{O}$ fractionation between the calcite stalagmite and cave drip water is a function of cave temperature $(T)$. In eastern China, precipitation mostly $(>75 \%)$ occurs in the summer and the vapor source is mainly the western North Pacific and Indian oceans. This seasonality and moisture source of the monsoon system have remained little changed during the late Holocene. Therefore, although multiple factors such as temperature and changes in moisture source and its $\delta^{18} \mathrm{O}$ can affect the $\delta^{18} \mathrm{O}$ of a stalagmite, rainfall amount is the dominant factor influencing stalagmite $\delta^{18} \mathrm{O}$ on annual to decadal scales in eastern China (Li et al., 1998a).

High-resolution (annual-to-decadal), precisely dated speleothem $\delta^{18} \mathrm{O}$ records of the six caves in the monsoonal region of eastern China were selected to study the temporal-spatial variability of EASM since the MWP (Fig. 2). Table 1 shows the locations of these caves and nearby cities where meteorological data and historic climate records can be obtained. All six $\delta{ }^{18} \mathrm{O}$ records have been published: the Dongge Cave record by Wang et al. (2005), the Furong Cave record by Li et al. (2011), the Heshang Cave record by Hu et al. (2008), the Buddha Cave record by Paulsen et al. (2003), the Wanxiang Cave record by Zhang et al. (2008) and the Shihua Cave record by Wan et al. (2011b). The stalagmites were dated by various methods such as ${ }^{230} \mathrm{Th} / \mathrm{U},{ }^{210} \mathrm{~Pb}$ and lamination counting to a time resolution as fine as year-to-subdecade for the last millennium. These records were generally compared with local rainfall records, and some of them were used to interpret historic events (e.g. Li et al., 1998b; Zhang et al., 2008) and matched with solar variability (e.g. Wang et al., 2005). Figure 3 (light curves) shows the original speleothem $\delta^{18} \mathrm{O}$ records. Yearly speleothem $\delta^{18} \mathrm{O}$ time series of the six records were obtained through a linear interpolation between points that are not annual resolution. In this study, time durations of the MWP, early and late LIA and modern since the Industrial Revolution were chosen (Crowley, 2000; Hughes and Diaz, 1994; Jansen et al., 2007). To work on multi-century durations, the chronologies of the records are precise enough within the uncertainties $(< \pm 15$ years).

In order to cross-check our results obtained from the speleothem $\delta^{18} \mathrm{O}$ records, DWI in 16 locations as well as the mean DWI in the three divisions of Huabei, Huanan and Low-Middle Yangtze River Drainage Basin were selected (Table 1). Chinese historical documentations are generally accurate in chronology and unambiguous in their description of dry/wet and warm/cold conditions (Zhang, 1988; Zheng et al., 1977, 2006). These records are based on abundant historic documents in China and have been calibrated with instrumental precipitation records. In this study, only the records back in AD 1471 or beyond were selected (Chinese Academy of Meteorological Sciences, 1981; Zhang et al., 2003). For the DWI records, climatic conditions are classified into five categories: 2 and -2 stand for very wet and very dry, respectively; 1 and -1 denote for wet and dry, respectively; and 0 represents normal. 


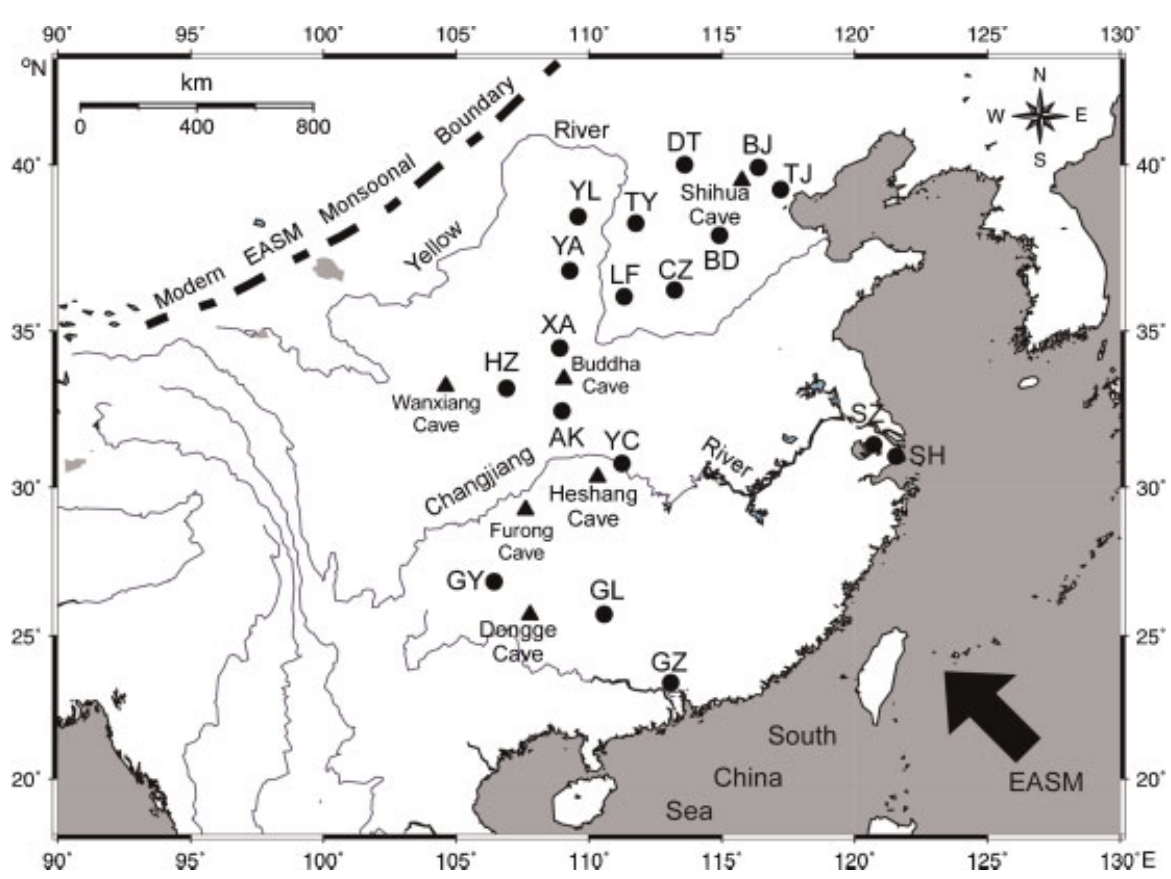

Figure 2. Location map showing the six caves discussed in the paper that have highresolution $\delta{ }^{18} \mathrm{O}$ records with good chronology control and 16 stations which have DWI since AD 1471, except Beijing record, which goes back to AD 960.

\section{Trends of speleothem $\delta^{18} \mathrm{O}$ data}

To identify EASM fluctuations, the trends of speleothem $\delta^{18} \mathrm{O}$ should be first determined for the six cave records. Let $x(t)$ represent the time series of the speleothem $\delta^{18} \mathrm{O}$ yearly data as shown in Fig. 3. From AD 900 to AD 2000, $x(t)$ fluctuates on various timescales (inter-annual, decadal and centennial) with many local maxima and local minima. Huang el al. (1998) developed empirical mode decomposition (EMD) to objectively obtain the trend. EMD is a non-parametric data-driven

Table 1. Information of six caves $\left(^{*}\right)$ and stations for historic DWI.

\begin{tabular}{|c|c|c|c|c|c|}
\hline & & MD & LIA-2 & LIA-1 & MWP \\
\hline Site name & Location & $2000-1850$ & $1849-1550$ & $1549-1250$ & $1250-960$ \\
\hline \multicolumn{2}{|l|}{ Huabei Division } & -0.028 & 0.076 & & \\
\hline Beijing (BJ) & $39.924^{\circ} \mathrm{N}, 116.381^{\circ} \mathrm{E}$ & -0.126 & 0.076 & 0.129 & 0.004 \\
\hline Tianjin (TJ) & $39.131^{\circ} \mathrm{N}, 117.203^{\circ} \mathrm{E}$ & 0.000 & 0.130 & & \\
\hline Shihua Cave* & $39^{\circ} 48^{\prime} \mathrm{N}, 115^{\circ} 54^{\prime} \mathrm{E}$ & -0.126 & -0.014 & -0.006 & 0.032 \\
\hline Baoding (BD) & $38.857^{\circ} \mathrm{N}, 115.500^{\circ} \mathrm{E}$ & 0.046 & -0.050 & & \\
\hline \multicolumn{2}{|c|}{ Low-Middle Yangtze River Division } & 0.099 & 0.139 & & \\
\hline Shanghai (SH) & $31.238^{\circ} \mathrm{N}, 121.469^{\circ} \mathrm{E}$ & 0.020 & 0.153 & & \\
\hline Suzhou (SZ) & $31.316^{\circ} \mathrm{N}, 120.619^{\circ} \mathrm{E}$ & 0.020 & 0.143 & & \\
\hline Yichang (YC) & $30.704^{\circ} \mathrm{N}, 111.285^{\circ} \mathrm{E}$ & 0.099 & 0.147 & & \\
\hline Heshang Cave* & $30^{\circ} 27^{\prime} \mathrm{N}, 110^{\circ} 25^{\prime} \mathrm{E}$ & 0.166 & -0.039 & 0.001 & 0.078 \\
\hline Huanan Division & & -0.025 & 0.093 & & \\
\hline Guilin (GL) & $25.282^{\circ} \mathrm{N}, 110.287^{\circ} \mathrm{E}$ & 0.053 & 0.070 & & \\
\hline Guangzhou (GZ) & $23.119^{\circ} \mathrm{N}, 113.261^{\circ} \mathrm{E}$ & -0.073 & 0.093 & & \\
\hline \multicolumn{6}{|c|}{ Other eastern China sites } \\
\hline Datong (DT) & $40.097^{\circ} \mathrm{N}, 113.296^{\circ} \mathrm{E}$ & 0.066 & -0.101 & & \\
\hline Taiyuan (TY) & $37.871^{\circ} \mathrm{N}, 112.569^{\circ} \mathrm{E}$ & -0.026 & -0.013 & & \\
\hline Linfen (LF) & $36.083^{\circ} \mathrm{N}, 111.514^{\circ} \mathrm{E}$ & -0.086 & -0.110 & & \\
\hline Changzhi (CZ) & $36.182^{\circ} \mathrm{N}, 113.106^{\circ} \mathrm{E}$ & -0.205 & -0.110 & & \\
\hline Yulin (YL) & $38.297^{\circ} \mathrm{N}, 109.757^{\circ} \mathrm{E}$ & -0.159 & -0.193 & & \\
\hline YanAn (YA) & $36.594^{\circ} \mathrm{N}, 109.471^{\circ} \mathrm{E}$ & -0.166 & -0.167 & & \\
\hline Xian (XA) & $34.262^{\circ} \mathrm{N}, 108.949^{\circ} \mathrm{E}$ & 0.060 & -0.067 & & \\
\hline Buddha Cave* & $33^{\circ} 40^{\prime} \mathrm{N}, 109^{\circ} 05^{\prime} \mathrm{E}$ & 0.343 & -0.191 & 0.013 & 0.059 \\
\hline Ankang (AK) & $32.690^{\circ} \mathrm{N}, 109.026^{\circ} \mathrm{E}$ & 0.278 & 0.217 & & \\
\hline Hanzhong (HZ) & $33.078^{\circ} \mathrm{N}, 107.034^{\circ} \mathrm{E}$ & 0.179 & 0.233 & & \\
\hline Wanxiang Cave* & $33^{\circ} 19^{\prime} \mathrm{N}, 105^{\circ} 00^{\prime} \mathrm{E}$ & -0.053 & 0.010 & -0.018 & -0.021 \\
\hline Guiyang (GY) & $26.577^{\circ} \mathrm{N}, 106.711^{\circ} \mathrm{E}$ & -0.106 & -0.013 & & \\
\hline Furong Cave* & $29^{\circ} 13^{\prime} \mathrm{N}, 107^{\circ} 54^{\prime} \mathrm{E}$ & -0.208 & 0.083 & 0.032 & -0.004 \\
\hline Dongge Cave* & $25^{\circ} 17^{\prime} \mathrm{N}, 108^{\circ} 50^{\prime} \mathrm{E}$ & -0.043 & -0.013 & 0.013 & -0.042 \\
\hline
\end{tabular}

All locations of the caves and stations are shown in Fig. 2. Three divisions including Huabei (northern China), Huanan (southern China) and LowMiddle Yangtze River Drainage Basin are climatic regions based on the meteorological observation over the past 60 years in China. The other sites also belong to monsoonal area of eastern China, but outside of the above three divisions. The calculated mean climatic conditions for the four periods are shown by the numerical numbers. For DWI, positive numbers indicate wet climate and negative numbers are dry climate. For the cave $\delta^{18} \mathrm{O}$ anomaly, positive values reflect dry climate, whereas negative numbers show wet climate. 
Figure 3. Time series of high-resolution (yearly) speleothem $\delta^{18} \mathrm{O}$ data from south to north at the (a) Dongge, (b) Furong, (c) Heshang, (d) Buddha, (e) Wanxiang and (f) Shihua caves. Here, the dashed curves represent the trends obtained using the EMD method. It is noted that all the trends show a similar pattern (except the recent increase of speleothem $\delta^{18} \mathrm{O}$ since 1800 except at the Wanxiang cave).
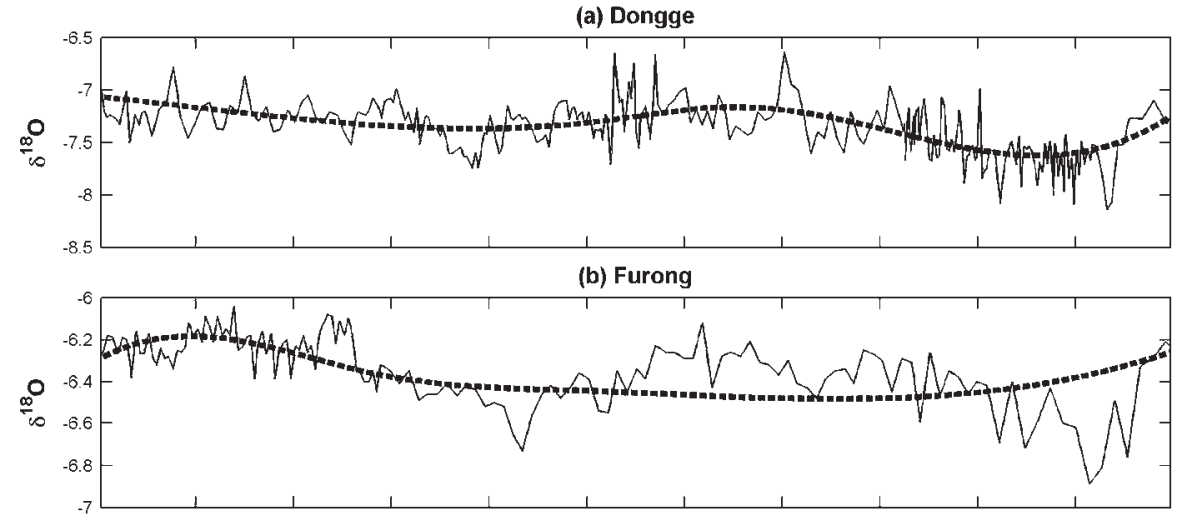

(c) Heshang

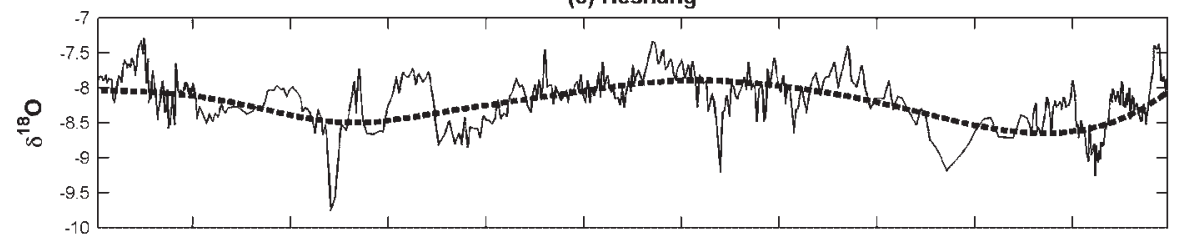

(d) Buddha
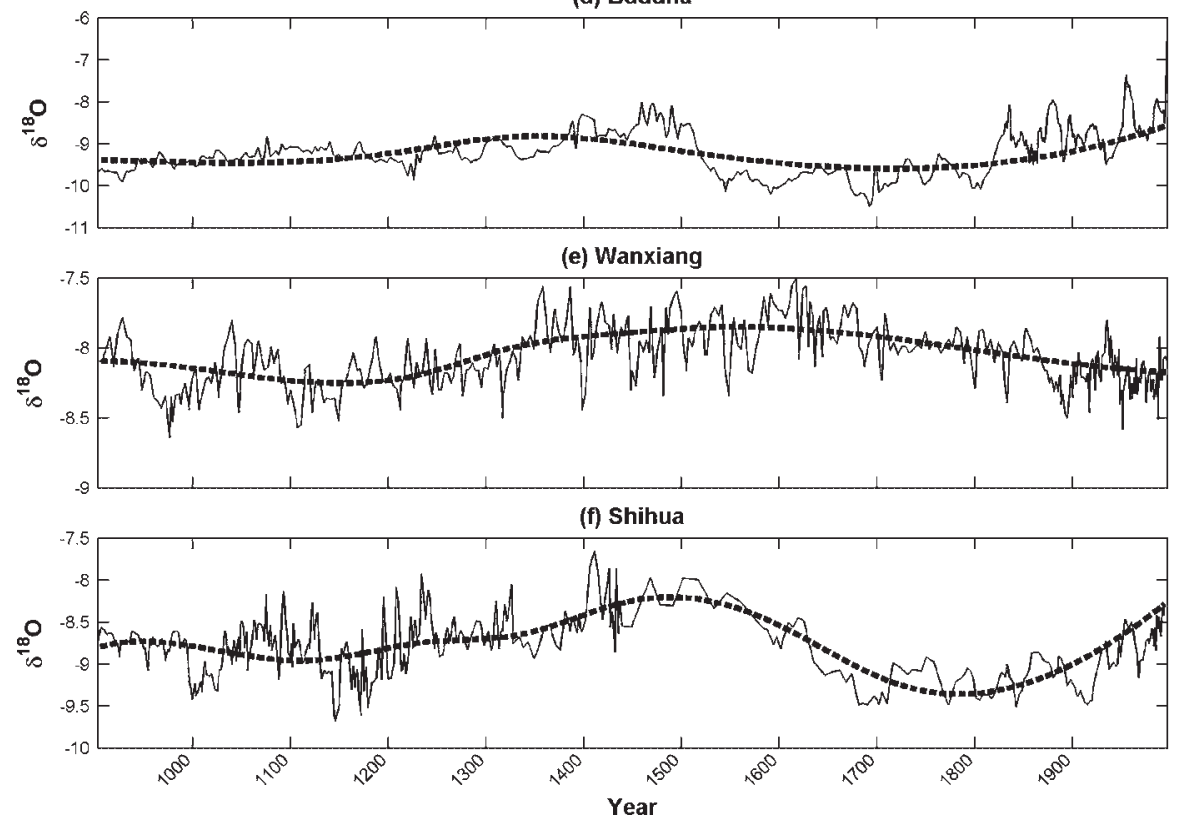

analysis tool that decomposes nonlinear non-stationary signals into intrinsic mode functions (IMFs). An IMF is a function that must satisfy two conditions according to the algorithm originally developed: (a) the difference between the number of local extrema and number of zero crossings must be zero or one; (b) the running mean value of the envelope defined by the local maxima and the envelope defined by the local minima is zero. The algorithm to decompose a signal into IMFs is then the following (Huang et al., 1998): First, the local minima and maxima of the signal $x(t)$ are identified. Second, the local maxima are connected together by a cubic spline interpolation (other interpolations are also possible), forming an upper envelope $e_{\max }(t)$. The same is done for local minima, providing a lower envelope $e_{\min }(t)$. Third, the mean of the two envelopes is calculated:

$$
m_{1}(t)=\left[e_{\max }(t)+e_{\min }(t)\right] / 2
$$

Such a procedure is shown in Fig. 4. Fourth, the mean is subtracted from the signal, providing the local detail:

$$
h_{1}(t)=x(t)-m_{1}(t)
$$

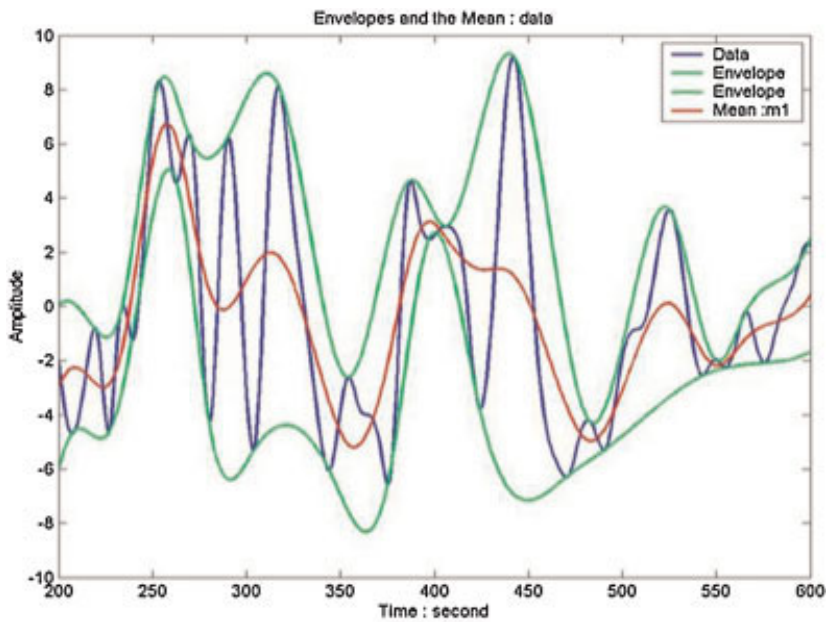

Figure 4. Illustration of the EMD process, with the blue curve denoting $x(t)$, the two green curves representing envelopes of local maxima $e_{\max }(t)$ and minima $e_{\min }(t)$ and the red curve referring to $m_{1}(t)=\left[e_{\max }(t)+e_{\min }(t)\right] / 2$. 
which is then considered to check whether it satisfies the above two conditions to be an IMF. If yes, it is considered as the first IMF and denoted

$$
x_{1}(t)=h_{1}(t)
$$

It is subtracted from the original signal and the first residual:

$$
r_{1}(t)=x(t)-x_{1}(t)
$$

which is taken as the new series in step 1. If $h_{1}(t)$ is not an IMF, a procedure called a 'sifting process' is applied as many times as

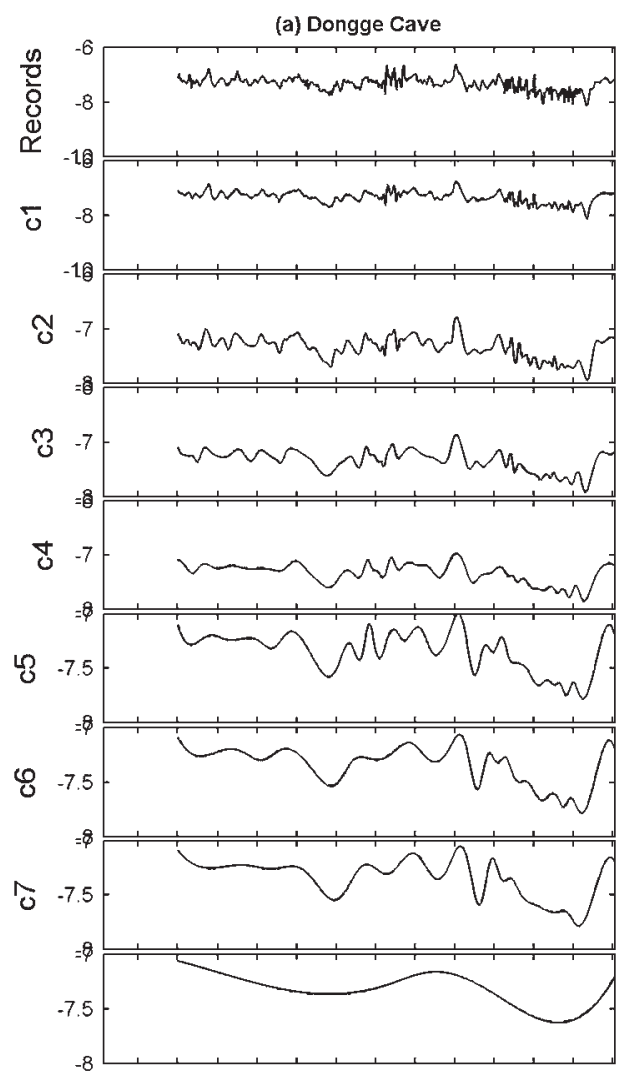

(d) Buddha Cave

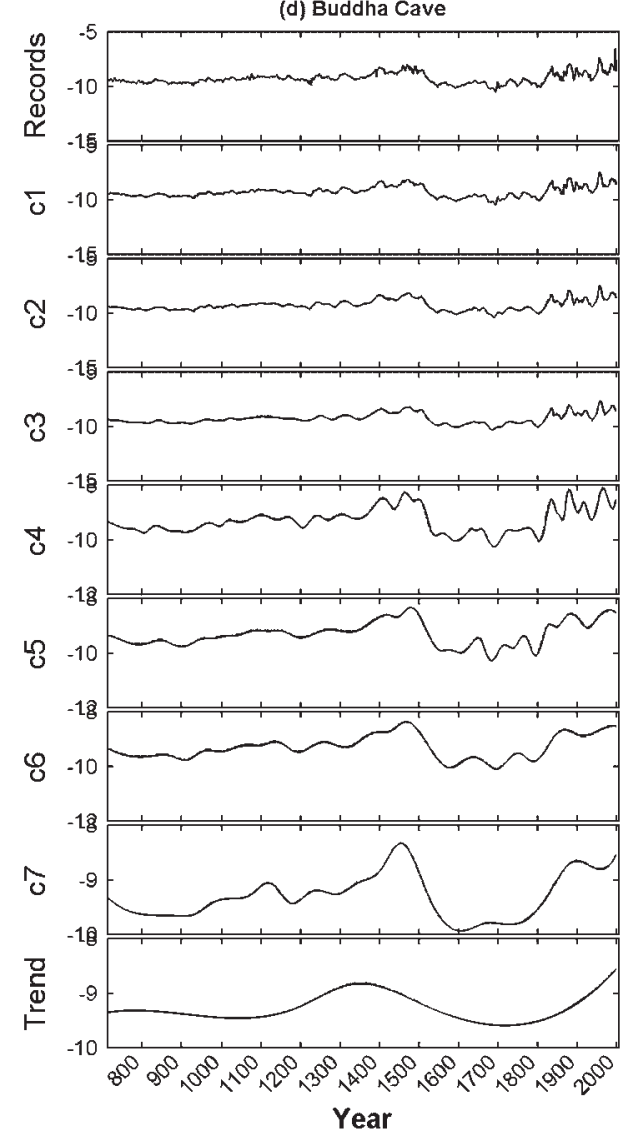

(b) Furong Cave

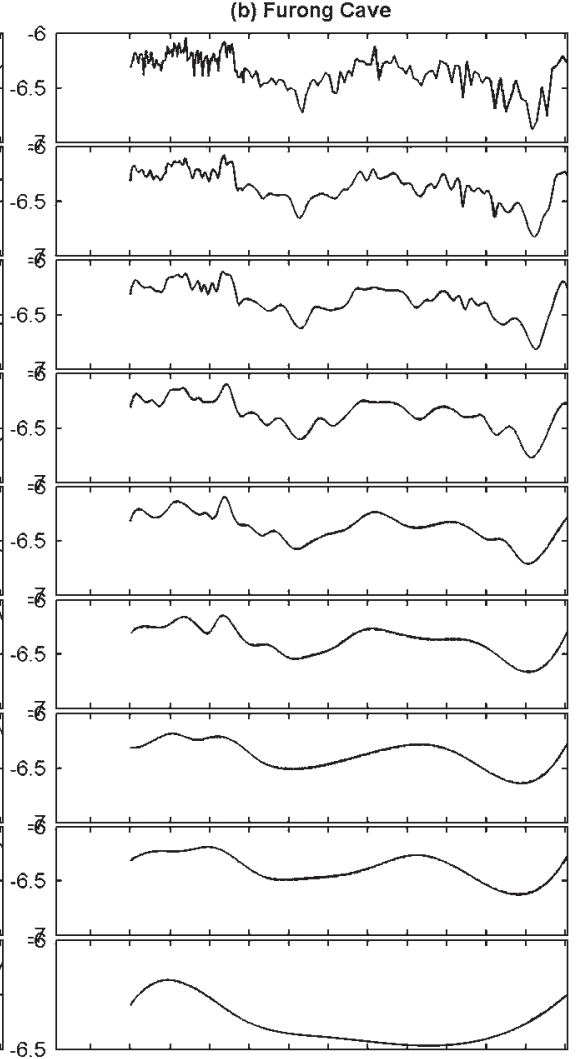

(e) Wanxiang Cave

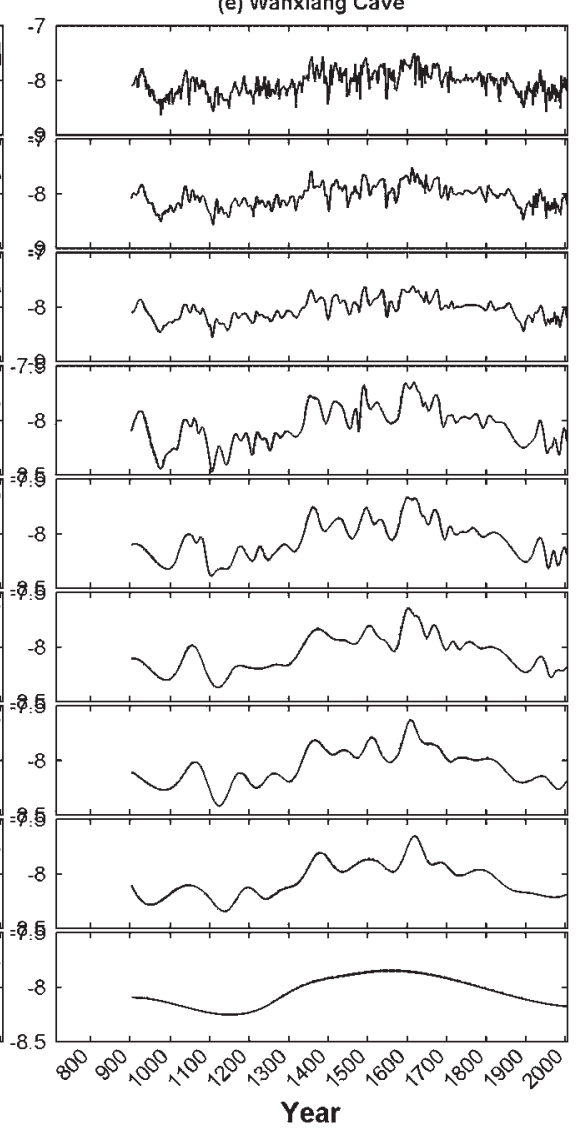

(c) Heshang Cave

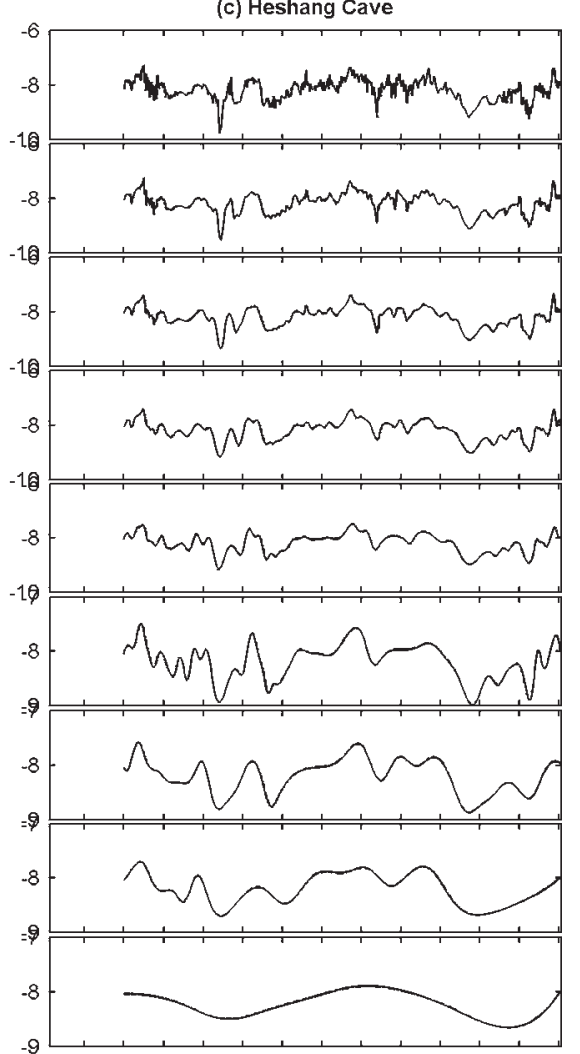

(f) Shihua Cave

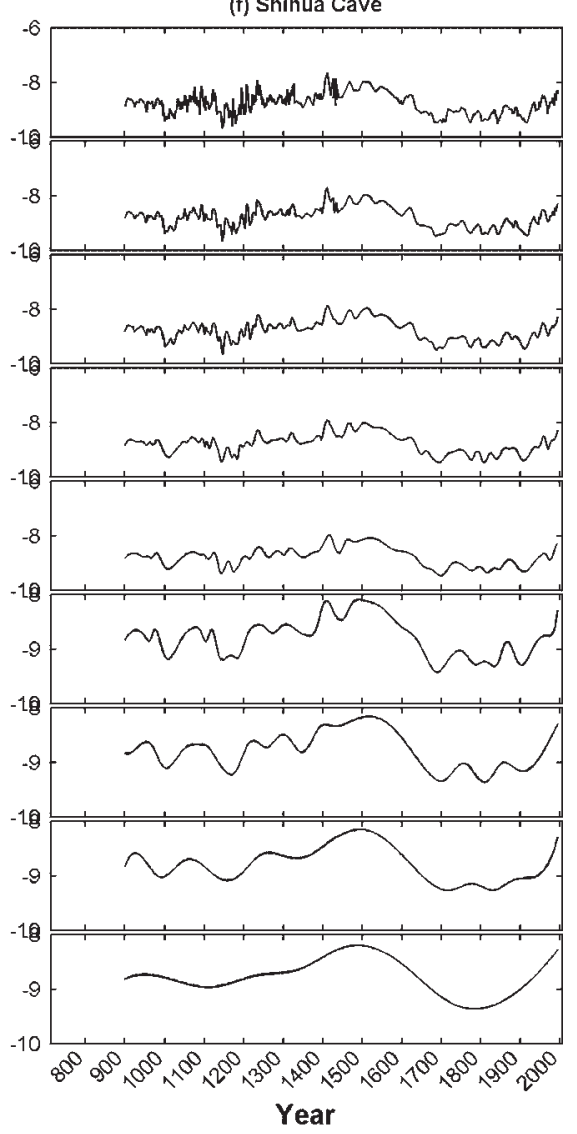

Figure 5. Functions $c_{1}(t)$ to $c_{7}(t)$ and the trends of the speleothem $\delta^{18} \mathrm{O}$ time series at the (a) Dongge, (b) Furong, (c) Heshang, (d) Buddha, (e) Wanxiang and (f) Shihua caves. 
necessary to obtain an IMF. In the sifting process, $h_{1}(t)$ is considered as the new data, and the same procedure applies. The IMFs are orthogonal, or almost orthogonal functions (mutually uncorrelated). This method does not require stationarity of the data and is especially suitable for nonstationary and nonlinear time series analysis.

By construction, the number of extrema decreases when going from one residual to the next; the above algorithm ends when the residual has only one extrema, or is constant, and in this case no more IMF can be extracted; the complete decomposition is then achieved in a finite number of steps. The signal $x(t)$ is finally written as the sum of mode time series $x_{i}(t)$ and the residual $r_{m}(t)$ :

$$
x(t)=\sum_{i=1}^{m} x_{i}(t)+r_{m}(t)
$$

where $x_{1}(t)$ has the highest temporal variability and $x_{m}(t)$ has the lowest temporal variability. The functions

$$
c_{k}(t)=x(t)-\sum_{i=1}^{k} x_{i}(t), \quad k=1,2, \ldots, m
$$

show the filtration of high-frequency variability from the signal $x(t)$ with $c_{1}(t)$ filtering out of $x_{1}(t), c_{2}(t)$ filtering out of $x_{1}(t)+x_{2}(t), \ldots$, and $c_{m}(t)$ is $r_{m}(t)$.

A residual $r_{m}(t)$ can be treated as a trend if its low-frequency variability occurs in all the functions $c_{1}(t), c_{2}(t), \ldots, c_{m}(t)$. In other words, the trend should not be filtered out by any methods. Figure 5 shows such a filtration process using the EMD method on the speleothem $\delta^{18} \mathrm{O}$ time series at the six caves. It is noted that the low-frequency variability represented by $r_{7}(t)$ (identified by the trend) occurs in $c_{1}(t), c_{2}(t), \ldots, c_{7}(t)$.

To identify the temporal variation in long timescales, four major periods are defined: MWP, LIA-1, LIA-2 and MD. Trends of the speleothem $\delta^{18} \mathrm{O}$ time series are similar in these caves (except for the Wanxiang Cave) (dashed curves in Fig. 3): it decreases slightly with time during MWP (AD 900-1250), with minimum values occurring around AD 1150 (strengthening of the EASM); increases with time during LIA-1 (AD 1250-1550), with maximum values appearing around AD 1500 (weakening of the EASM); decreases with time during LIA-2 (AD 15501850), with minimum values occurring around AD 1800 (strengthening of the EASM); and increases with time during MD (AD 1850-2000) (weakening of the EASM). However, the trends of the speleothem $\delta^{18} \mathrm{O}$ time series for the Wanxiang Cave show an evident decrease during MD (Fig. 3).

\section{Speleothem $\delta^{18} \mathrm{O}$ anomaly}

The detrended data,

$$
\hat{x}(t)=x(t)-r_{m}(t)
$$

is called the speleothem $\delta^{18} \mathrm{O}$ anomaly, which changes on various timescales at the six caves (Fig. 6). With these time series of speleothem $\delta^{18} \mathrm{O}$ anomaly, spectral analysis has been conducted. The power spectra with a confidence level of $95 \%$ show an evident period of 128 years for all six caves, and other periods such as 42-year and 64-year cycles in different records (Fig. 7).

Many studies of natural archives have shown the wide periodic dominance in the 40- to 128-year band, e.g. in tree rings (Gray et al., 2004; Ogurtsov et al., 2002; Ware and Thomson, 2000), estuarine fossil pigments (Hubeny et al., 2006), marine sediments and fish scales (Berger et al., 2004). In tree ring records, the 42-year and 64-year periodicities were found to reflect the Atlantic Multidecadal Oscillation (AMO), which plays a role in the North Atlantic climate by producing

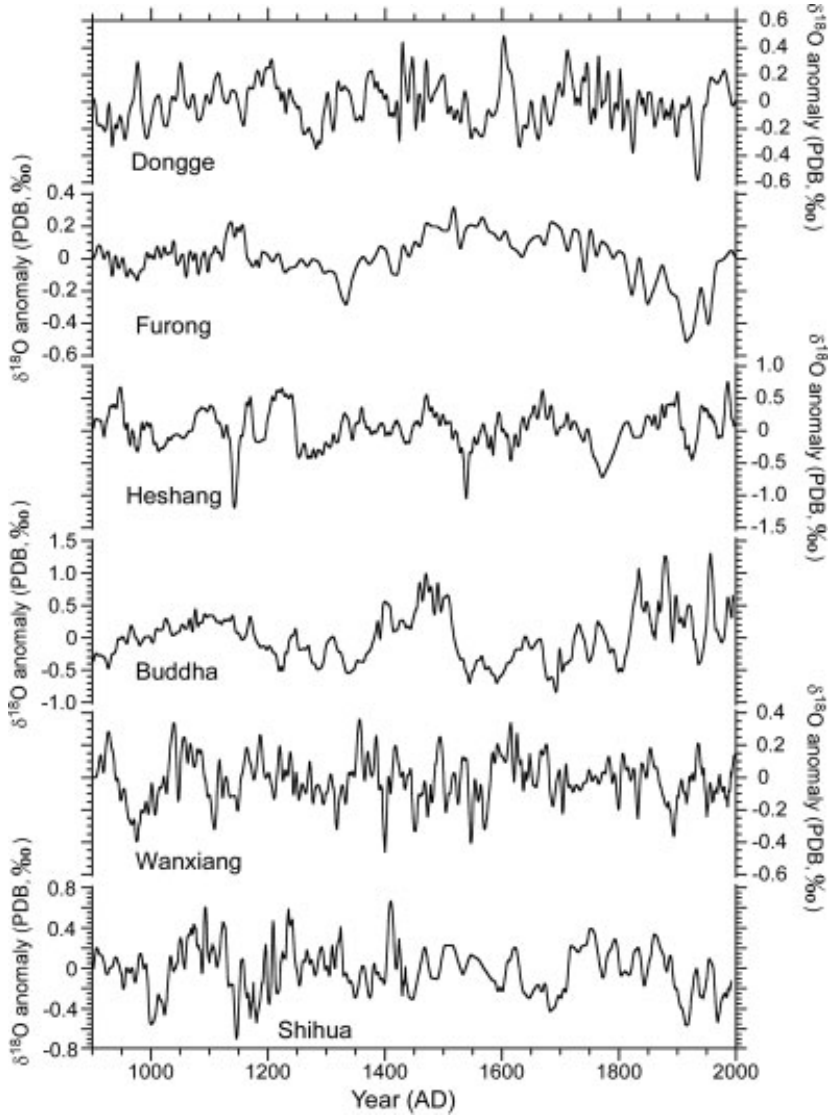

Figure 6. Detrended speleothem $\delta^{18} \mathrm{O}$ time series at the six caves.

anomalous geopotential heights over the fall and summer seasons (Enfield and Mestas-Nuñez, 1999; Gray et al., 2004; Hubeny et al., 2006). Similar to the AMO, multidecadal variability of climatic proxies is found in western North America (Gray et al., 2003) and the Northwest Pacific Basin (Delworth and Mann, 2000; Ware and Thomson, 2000). It is generally accepted that the 64- to 140-year band may reflect the respective changes in the length of the solar Gleissberg cycle, which is often centered at 88-98 years (Gleissberg, 1944; Ogurtsov et al., 2002). Sunspot numbers (e.g. Wolf numbers) have wide periodic dominance in the 64- to 128-year band by wavelet filtered analysis (Kane, 1999; Ogurtsov et al., 2002). Despite some debate about whether the small variation in solar activity could significantly affect the low atmospheric climates, many studies show that the multidecadal variability of regional climates may be attributed to the solar-oceanicatmospheric connections. For instance, multidecadal oceanic fluctuations associated with the $\mathrm{AMO}$ are teleconnected with Pacific Basin modes via the AO and a hypothesized atmospheric bridge at high latitudes (Honda et al., 2001). In combination with tropical Pacific-Indian Ocean forcing and internal processes, the $\mathrm{AMO}$ is influenced by the North Atlantic Oscillation (NAO) and Arctic Oscillation (AO), which are partially driven by North Atlantic sea-surface temperatures (SSTs) (Hoerling et al., 2001; Sutton and Hodson, 2003). It is acceptable that changes in solar activity such as sunspot numbers can cause variations of SST, which further affect atmospheric circulations by altering evaporation, precipitation and ocean-atmosphere heat exchanges. Delworth and Mann (2000) showed that the AMO is related to changes in thermohaline circulation and meridional heat flux. Hence we may hypothesize that changes in solar activity may affect SST and atmospheric circulations on ocean basins such as $\mathrm{NAO}$, Pacific Decadal Oscillation (PDO) and AO. The surface 


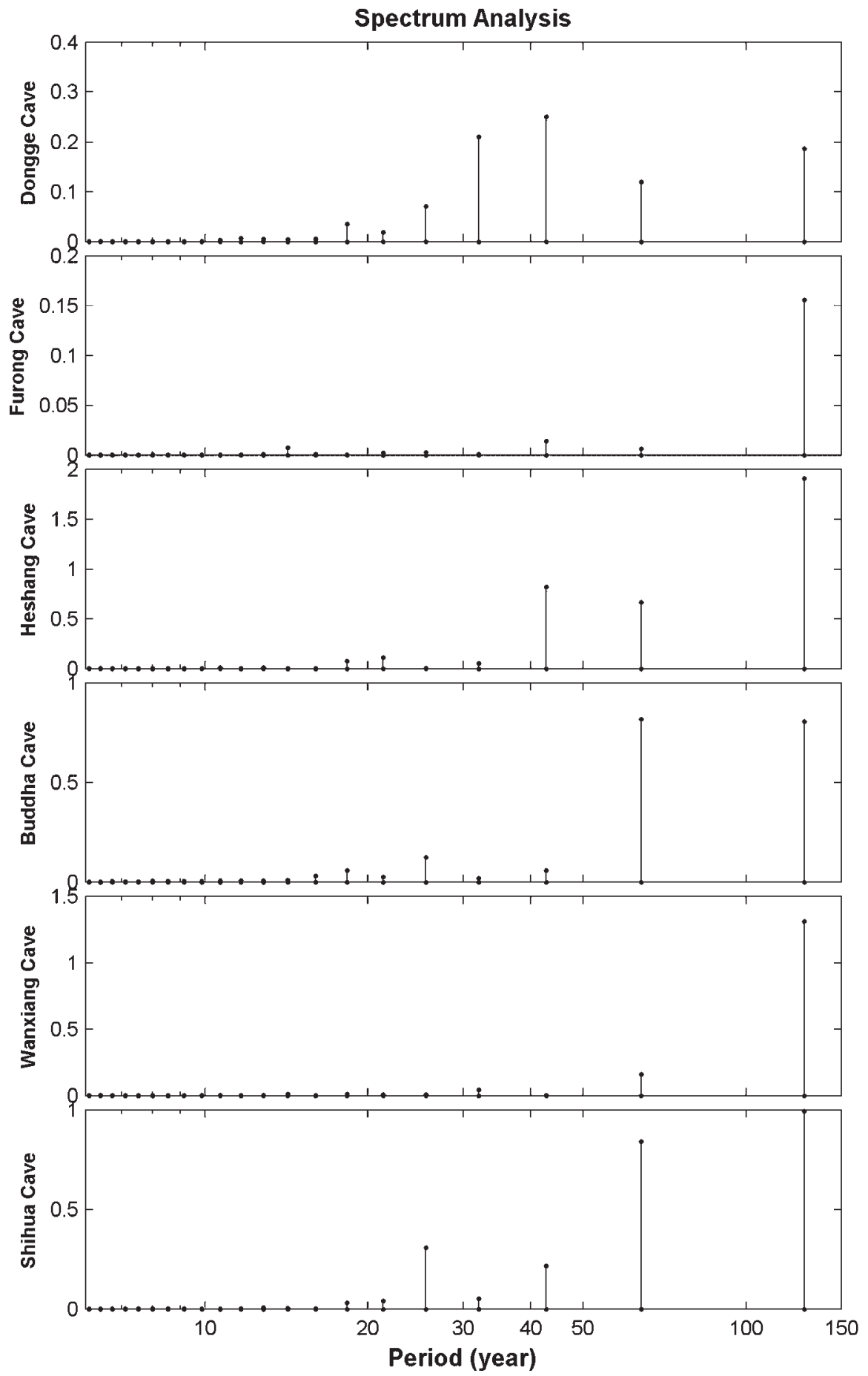

Figure 7. Power spectra of the detrended speleothem $\delta^{18} \mathrm{O}$ time series at the six caves. Here the horizontal axis shows the period. It is noted that the period of 128 years is very evident in all the caves.

changes lead to changes in thermohaline circulation and meridional heat flux that cause multidecadal climate fluctuations.

It is interesting to see that all six records have 128-year periodicity (Fig. 7). This lower frequency band may imply that the solar variability has a broad impact on the EASM, with minor modification/interruption of local or regional complexes in climatic settings. If considering the 64 -year periodicity as a harmonic of 128 -year periodicity, the 64-year periodicity could appear in all six records. However, this 64-year cycle is not shown in the Wanxiang and Furong Cave records. Actually, the shorter periodicities ( $<128$ years) are not seen in Wanxiang and Furong Cave records, which are the two further inland cave sites (Fig. 7). If this is the actual situation, it may imply that the shorter periodicities ( 64 and 42 years) are probably more related to oceanic changes which affect the climate of the area closer to the ocean (e.g. Shihua and Dongge Cave sites). In view of the physical meanings of speleothem $\delta^{18} \mathrm{O}$, variation of the $\delta^{18} \mathrm{O}$ on longer timescales may not reflect rainfall amount change but moisture source, etc., under the influence of the summer monsoon. The 128-year cycle thus may indicate the speleothem $\delta^{18} \mathrm{O}$ change caused by changes in moisture source (including its $\delta^{18} \mathrm{O}$ and pathway, such as Pacific vs. Indian Ocean). On this timescale, the speleothem $\delta^{18} \mathrm{O}$ may not present rainfall amount change. In this case, one should think about the climatic implication of the similarity of 
the Holocene trend in most speleothem $\delta^{18} \mathrm{O}$ records. The high frequent fluctuations of the speleothem $\delta^{18} \mathrm{O}$ may reflect mainly local rainfall changes. Figure 7 shows that the 64-year and 42.7-year cycles are clear monsoonal rainfall cycles in Shihua, Dongge and Heshang Cave sites, which are closer to the ocean. The 25.6-year cycle in the Shihua Cave record (northernmost) and 32-year cycle in the Dongge Cave record (southernmost) show more regional differences in rainfall cycles even though the two sites are close to the coastal area.

To identify the temporal variation in the four major periods (MWP, LIA-1, LIA-2 and MD), the speleothem $\delta^{18} \mathrm{O}$ anomaly $\hat{x}(t)$ is averaged within the four periods $\left(\hat{x}_{\text {MWP }}, \hat{x}_{\text {LIA-1 }}, \hat{x}_{\text {LIA-2 }}, \hat{x}_{\text {MD }}\right)$ for each cave (Table 1$)$. Figure 8 shows the spatial distribution of $\hat{x}_{\mathrm{MWP}}, \hat{x}_{\mathrm{LIA}-1}, \hat{x}_{\mathrm{LIA}-2}, \hat{x}_{\mathrm{MD}}$, respectively.

The speleothem $\delta^{18} \mathrm{O}$ anomaly (or the monsoonal rainfall anomaly) reveals an east-west dipole pattern with alternating $(+,-)$ signs as the climate period shifts. During the MWP and LIA-1, the eastern part of eastern China has a positive anomaly $\left(\hat{x}_{\text {MWP }}>0, \hat{x}_{\text {LIA-1 }}>0\right)$, referring to drier climatic condition; and the western part of eastern China has a negative anomaly $\left(\hat{x}_{\mathrm{MWP}}<0, \hat{x}_{\mathrm{LIA}-1}<0\right)$, referring to wetter conditions. During the LIA-2, the pattern flips, in that the eastern part of eastern China has negative anomaly $\left(\hat{x}_{\mathrm{LIA}-1}<0\right)$, referring to increase of summer rainfall; and the western part of eastern China has a positive anomaly $\left(\hat{x}_{\mathrm{LIA}-1}>0\right)$, referring to decrease of summer rainfall. During the MD, the pattern flips back (similar to the MWP and LIA-1), in that the eastern part of eastern China has a positive anomaly $\left(\hat{x}_{\mathrm{MD}}>0\right)$; and the western part of eastern China has a negative anomaly $\left(\hat{x}_{\mathrm{MD}}<0\right)$.

For DWI records, the mean values for each station at four periods are calculated and listed in Table 1. Only Beijing DWI is 1000 years long, so that the rest of the DWI records have only mean values for periods of LIA-2 and MD. For LIA-2, which is the second half of the Little Ice Age, the mean DWI values in all three divisions are positive, with mean a wet climate in this period in the eastern part of eastern China. This agrees with the speleothem $\delta^{18} \mathrm{O}$ records, which showed a negative value for wetter climatic conditions during LIA-2. In contrast, the mean DWI values of the most western sites (DT, TY, LF, CZ, YL, YA, $X A, G Y)$ were negative numbers, showing dry climates in the same period. We admit that the cave records are too sparse, especially for the northern part, so that the curves drawn in Fig. 8 are not accurate enough to compare with the DWI records. For LIA-1, the Beijing DWI record supports the speleothem reconstruction, showing a wet climate in that area. However, for the MWP the cave record indicates a dry condition in Beijing area but the Beijing DWI shows a small positive value, which may have some uncertainty. Nevertheless, the Beijing mean DWI value does not show a significant dry climate during MWP. The comparison of the two kinds of records for the modern period (MD) do not compare well. The mean DWI values of most sites in eastern China are negative numbers except for the Low-Middle Yangtze River Division, reflecting dry climate conditions. Mean values of the
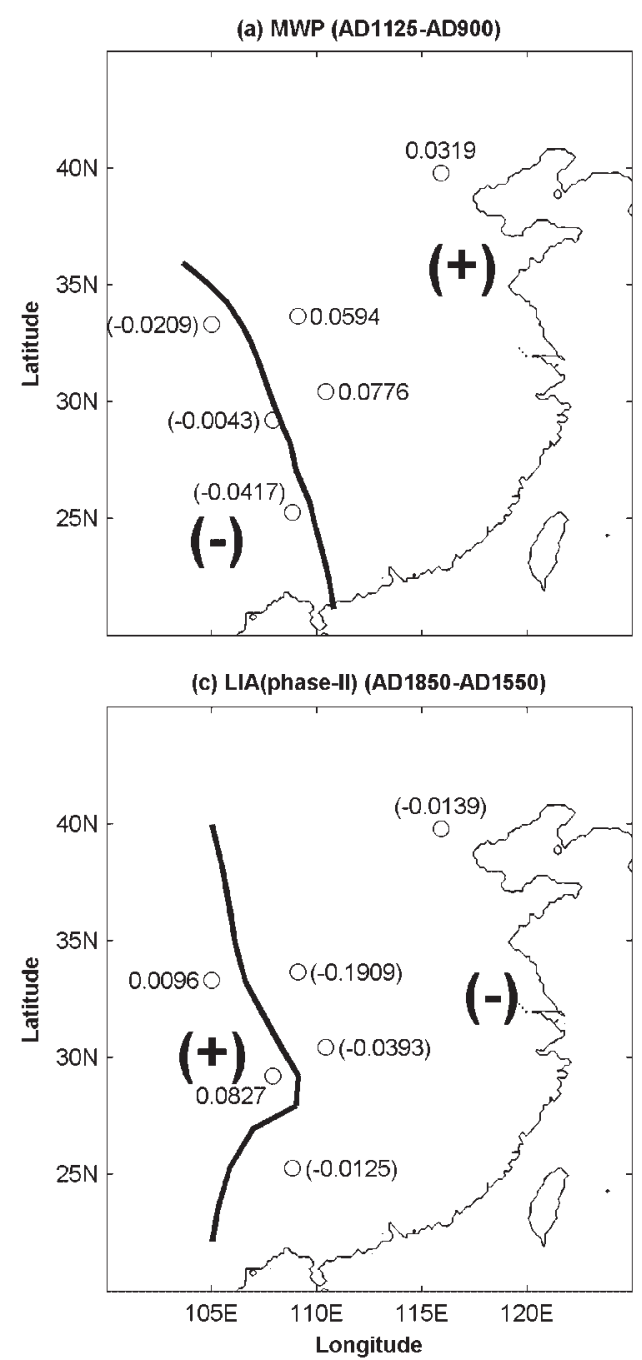

(b) LIA(phase-I) (AD1550-AD1125)

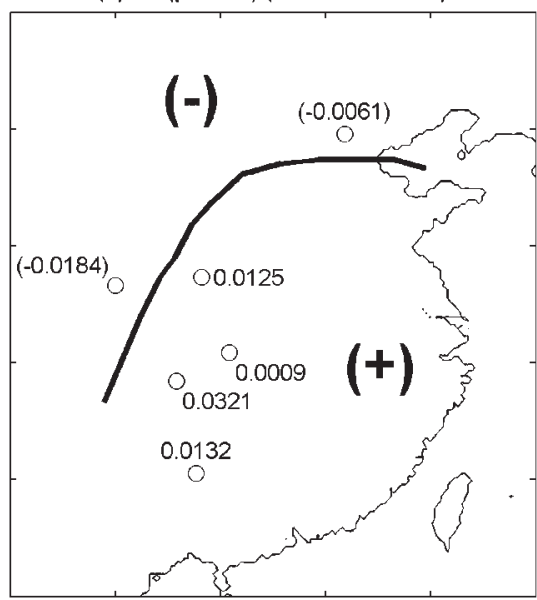

Modern (AD2000-AD1850)

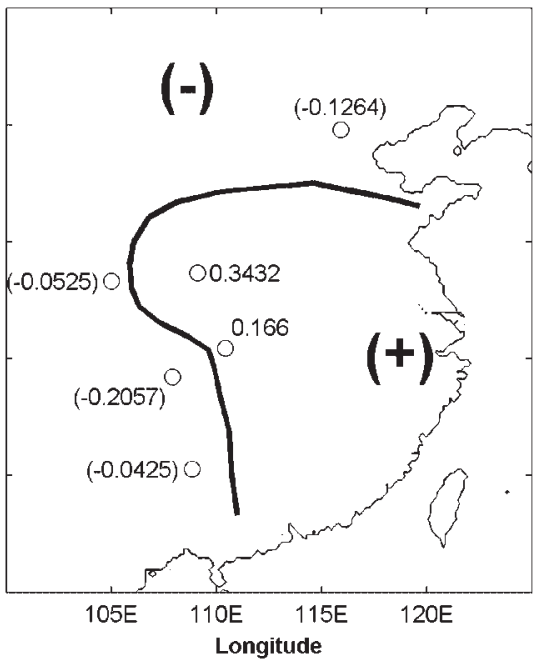

Figure 8. Spatial distributions of mean $\delta^{18} \mathrm{O}$ anomalies during (a) MWP, (b) LIA-1, (c) LIA-2 and (d) MD. 
speleothem $\delta^{18} \mathrm{O}$ anomalies in the western part of eastern China are negative, referring to wetter conditions. Although the global warming trend and industrial pollution can affect both the relationship of speleothem $\delta^{18} \mathrm{O}$-temperature and the relationship of monsoonal strength with rainfall pattern, the spatial variation of the EASM strength during the MD shown in Fig. 8 needs more evidence for clarification.

Although the distribution patterns of the EASM climates during the four periods are roughly reconstructed, it is clear that the summer monsoon strength cannot produce a similar moisture condition over eastern China on annual-to-centennial timescales. The spatial patterns also change with time. No single speleothem record can interpret the paleoclimate for the whole of eastern China. In addition, the monsoonal climatic patterns are not only warm/wet and cold/dry, but also can be warm/dry and cold/wet, depending on location and time. In order to reconstruct detailed monsoonal climates and to understand their forcing factors, more high-resolution speleothem records distributed in broad regions are needed.

\section{Conclusions}

Temporal and spatial variability of the EASM climate (in terms of rainfall) since AD 900 has been identified from highresolution speleothem $\delta^{18} \mathrm{O}$ data (yearly) at six caves (Dongge, Furong, Heshang, Wanxiang, Buddha, Shihua) in eastern China. The trends of the speleothem $\delta^{18} \mathrm{O}$ time series at these caves were obtained using the EMD method. The trends of speleothem $\delta^{18} \mathrm{O}$ imply strengthening of the EASM during the MWP (AD 900-1250) and LIA-2 (AD 1550-1850), respectively; and weakening of the EASM during LIA-1 (AD 1250-1550) and MD (AD 1850-2000), respectively. The detrended highresolution speleothem $\delta^{18} \mathrm{O}$ data (i.e. anomaly) show local climatic conditions, with a negative anomaly reflecting wet climates and vice versa. The spectral analysis on the speleothem $\delta^{18} \mathrm{O}$ anomaly time series shows that all six records have a 128-year periodic cycle, and three locations close to the ocean have 64-year and 42-year periodicities as well. These cycles are probably evidence of solar influence on the EASM. The temporally averaged speleothem $\delta{ }^{18} \mathrm{O}$ anomaly for the four climate periods during the last millennium reveals an east-west dipole pattern, with alternating $(+,-)$ signs as the climate period shifts: dry climates (wet climates) in the eastern (western) part of eastern China during the MWP and LIA-1, wet climates (dry climates) in the eastern (western) part of eastern China during the LIA-2, and dry climates (wet climates) in the eastern (western) part of eastern China during the MD. Therefore the monsoonal climatic patterns have different combinations in terms of temperature and wetness depending on location and time. No single speleothem record can represent the climatic conditions in a broad region of eastern China.

Acknowledgements. We gratefully acknowledge the National Science Council of Taiwan (NSC 98-3114-E-006 -014, NSC 982116-M-006 -003 and NSC 100-3113-E-002 -009). H.-C. Li acknowledges the support of the National Science Foundation (grant no. 40930743). The authors thank Prof. Paul Williams at the University of Auckland, New Zealand, and another anonymous reviewer who provided useful review comments to improve the manuscript.

Abbreviations. AMO, Atlantic Multidecadal Oscillation; AO, Arctic Oscillation; DWI, dryness/wetness index; EAM, East Asian monsoon; EASM, East Asian Summer Monsoon; EMD, empirical mode decomposition; IMF, intrinsic mode function; LIA, Little Ice Age; MD, modern period; MWP, Medieval Warm Period; NAO, North Atlantic Oscillation; PDO, Pacific Decadal Oscillation.

\section{References}

Bar-Matthews M, Ayalon A, Gilmour M, et al. 2003. Sea-land oxygen isotopic relationships from planktonic foraminifera and speleothems in the Eastern Mediterranean region and their implication for paleorainfall during interglacial intervals. Geochimica et Cosmochimica Acta 67: 3181-3199.

Baskaran M, Iliffe TM. 1993. Age determination of recent cave deposits using excess ${ }^{210} \mathrm{~Pb}$ : a new technique. Geophysics Research Letters 20: 603-606.

Berger WH, Schimmelmann A, Lange CB. 2004. Tidal cycles in the sediments of Santa Barbara Basin. Geology 32: 329-332.

Chinese Academy of Meteorological Sciences. 1981. Yearly Charts of Dryness/Wetness in China for the Last 500-Year Period, Beijing. SinoMap: Beijing (in Chinese).

Crowley TJ. 2000. Causes of climate change over the past 1000 years. Science 289: 270-277.

Delworth TL, Mann ME. 2000. Observed and simulated multidecadal variability in the Northern Hemisphere. Climate Dynamics 16: 661676.

Ding YH, Ren GY. (eds). 2008. Scientific Introduction of Climate Change of China. Meteorological Press: Beijing (in Chinese).

Ding ZL, Liu TS, Rutter NW, et al. 1995. Ice-volume forcing of East Asia winter monsoon variations in the past 800,000 years. Quaternary Research 44: 149-159.

Edwards RL, Chen JH, Wasserburg GJ. 1986/87. ${ }^{238} \mathrm{U}^{234}{ }^{23-}{ }^{230} \mathrm{Th}^{232} \mathrm{Th}$ systematics and precise measurement of time over the past 500,000 years. Earth and Planetary Science Letters 81: 175-192.

Enfield DB, Mestas-Nuñez AM. 1999. Multiscale variabilities in global sea surface temperatures and their relationship with tropospheric climate patterns. Journal of Climate 12: 2719-2733.

Fairchild IJ, Smith CL, Baker A, et al. 2006. Modification and preservation of environmental signals in speleothems. Earth-Science Reviews 75: 105-153.

Gleissberg W. 1944. A table of secular variations of the solar cycle. Terrestrial Magnetic Field and Atmospheric Electricity 49: 243.

Gray ST, Betancourt JL, Fastie CL, et al. 2003. Patterns and sources of multidecadal oscillations in drought-sensitive tree-ring records from the central and southern Rocky Mountains. Geophysical Research Letters 30: 1316

Gray ST, Graumlich LJ, Betancourt JL, et al. 2004. A tree-ring based reconstruction of the Atlantic Multidecadal Oscillation since 1567 A.D. Geophysical Research Letters 31: L12205.

Guo QY, Cai JN, Shao XM, et al. 2003. Interdecadal variability of East-Asian summer monsoon and its impact on the climate of China. Acta Geographica Sinica 4: 569-576 (in Chinese with English abstract).

Hoerling MP, Hurrell JW, Xu T. 2001. Tropical origins for recent climate change. Science 292: 90-92.

Honda M, Nakamura H, Ukita J, et al. 2001. Interannual seesaw between the Aleutian and Icelandic Lows. Part I: Seasonal dependence and life cycle. Journal of Climate 14: 1029-1042.

Hu CY, Henderson GM, Huang J, et al. 2008. Quantification of Holocene Asian monsoon rainfall from spatially separated cave records. Earth and Planetary Science Letters 266: 221-232.

Huang NE, Shen Z, Long SR, et al. 1998. The empirical mode decomposition method and the Hilbert spectrum for non-stationary time series analysis. Proceedings of the Royal Society A 454: 903-995.

Hubeny JB, King JW, Santos A. 2006. Subdecadal to multidecadal cycles of Late Holocene North Atlantic climate variability preserved by estuarine fossil pigments. Geology 34: 569-572.

Hughes MK, Diaz HF. 1994. Was there a 'Medieval Warm Period' and if so, when and where? Climatic Change 26: 109-142.

Jansen E, Overpeck J, Briffa KR, et al. 2007. Palaeoclimate. In Climate Change 2007: The Physical Science Basis. Contribution of Working Group I to the Fourth Assessment Report of the Intergovernmental Panel on Climate Change, Solomon S, Qin D, Manning M, Chen Z, Marquis M, Averyt KB, Tignor M, Miller HL (eds). Cambridge University Press: Cambridge, UK; 435-484.

Kane RP. 1999. Prediction of the sunspot maximum of solar cycle 23 by extrapolation of spectral components. Solar Physics 189: 217.

Ku T-L, Li H-C. 1998. Speleothems as high-resolution paleoenvironment archives: records from northeastern China. Journal of Earth System Science 107: 321-330. 
Li H-C, Ku T-L, Stott LD, et al. 1998a. Applications of interannualresolution stable isotope records of speleothem: climatic changes in Beijing and Tianjin, China during the past 500 years: the $\delta^{18} \mathrm{O}$ record. Science in China (Series D) 41: 362-368.

Li H-C, Ku T-L, Chen W-J, et al. 1998b. Application of high-resolution stable isotope records in stalagmites: deforestation due to construction of Beijing during the Yuan dynasty: the $\delta^{13} \mathrm{C}$ record. Geological Reviews 44: 456-463.

Li H-C, Lee Z-H, Wan N-J, et al. 2011. Interpretations of $\delta^{18} \mathrm{O}$ and $\delta{ }^{13} \mathrm{C}$ in aragonite stalagmites from Furong Cave, Chongqing, China: a 2000-year record of monsoonal climate. Journal of Asia Earth Sciences 40: 1121-1130.

Ludwig KR, Simmons KR, Szabo BJ, et al. 1992. Mass-spectrometric ${ }^{230} \mathrm{Th}-{ }^{234} \cup-{ }^{238} \mathrm{U}$ dating of the Devils Hole calcite vein. Science 258: 284-287.

McDermott F. 2004. Palaeo-climate reconstruction from stable isotope variations in speleothems: a review. Quaternary Science Reviews 23: 901-918.

Ogurtsov MG, Kocharov GE, Lindholm M, et al. 2002. Evidence of solar variation in tree-ring-based climate reconstructions. Solar Physics 205: 403-417.

Paulsen DE, Li H-C, Ku T-L. 2003. Climate variability in central China over the last 1270 years revealed by high-resolution stalagmite records. Quaternary Science Reviews 22: 691-701.

Richards DA, Dorale JA. 2003. Uranium-series chronology and environmental applications of speleothems. In Uranium-Series Geochemistry, Bourdon B, Henderson GM, Lundstrom CC, Turner SP (eds). Mineralogical Society of America: Washington, DC; 407-460.

Shen C-C, Edwards RL, Cheng H, et al. 2002. Uranium and thorium isotopic and concentration measurements by magnetic sector inductively coupled plasma mass spectrometry. Chemical Geology 185 165-178.

Shi N, Zhu QG, Wu BG. 1996. The East Asian summer monsoon in relation to large scale weather: climate anomaly in China for last 40 years. Scientia Atmospherica Sinica 20: 575-583. (in Chinese with English abstract).

Shopov YY, Ford DC, Schwarcz HP. 1994. Luminescent microbanding in speleothems: high resolution chronology and paleoclimate. Geology 22: 407-410.

Sutton RT, Hodson DLR. 2003. Influence of the ocean on North Atlantic climate variability 1871-1999. Journal of Climate 16: 3296-3313.

Tan M, Hou J, Cheng H. 2002. Methodology of quantitatively reconstructing paleoclimate from annually laminated stalagmites. Quaternary Science 22: 209-219. (in Chinese with English abstract).

Wan N-J, Chung WL, Li H-C, et al. 2011a. The comparison of speleothem $\delta^{18} \mathrm{O}$ records from eastern China with solar insolation, ice core and marine records: similarities and discrepancies on different time scales. Journal of Asia Earth Sciences 40: 1151-1163.

Wan N-J, Li H-C, Liu Z-Q, et al. 2011b. Spatial variations of monsoonal rain in eastern China: instrumental, historic and speleothem records. Journal of Asia Earth Sciences 40: 1139-1150.

Wang YB, Liu XQ, Herzschuh U. 2010. Asynchronous evolution of the Indian and East Asian Summer Monsoon indicated by Holocene moisture patterns in monsoonal central Asia. Earth-Science Reviews 103: 135-153.

Wang YJ, Cheng H, Edwards RL, et al. 2001. A high-resolution absolutedated late Pleistocene monsoon record from Hulu Cave, China. Science 294: 2345-2348.

Wang YJ, Cheng H, Edwards RL, et al. 2005. The Holocene Asian monsoon: links to solar changes and north Atlantic climate. Science 308: 854-857.

Wang YJ, Cheng H, Edwards RL, et al. 2008. Millennial- and orbitalscale changes in the East Asian monsoon over the past 224,000 years. Nature 451: 1090-1093.

Ware DM, Thomson RE. 2000. Interannual to multidecadal timescale climate variations in the northeast Pacific. Journal of Climate 13 3209-3220

Yuan D, Cheng H, Edwards RL, et al. 2004. Timing, duration, and transition of the last interglacial Asian monsoon. Science 304: 575578

Zhang DE. 1988. The method for reconstruction of the dryness/wetness series and the winter temperature series in China for the last 500 years and its reliability. In The Reconstruction of Climate in China for Historical Time, Zhang JC (ed.). Science Press: Beijing; 18-39.

Zhang DE, Li XQ, Liang YY. 2003. Continuation (1992-2000) of the yearly charts of dryness/wetness in China for the last 500 years period. Journal of Applied Meteorological Science 14: 379-388 (in Chinese with English abstract).

Zhang DE, Li H-C, Ku T-L, et al. 2010. On linking climate to Chinese dynastic change: spatial and temporal variations of monsoonal rain. Chinese Science Bulletin 55: 77-83.

Zhang PZ, Cheng H, Edwards RL, et al. 2008. A test of climate, sun, and culture relationships from an 1810-year Chinese cave record. Science 322: 940-942.

Zheng JY, Wang WC, Ge QS, et al. 2006. Precipitation variability and extreme events in Eastern China during the past 1500 years. Terrestrial, Atmospheric and Oceanic Sciences 17: 579-592.

Zheng SZ, Zhang FC, Gong GF. 1977. On the change in climate wetness in southeastern China over the past 2,000 years. In Collection of Papers on Climate Change and Extra Long-Term Prediction, Compiled by China Meteorological Administration. Science Press: Beijing; 29-32 (in Chinese). 